\title{
COVID-19: age, Interleukin-6, C-reactive protein, and lymphocytes as key clues from a multicentre retrospective study
}

Aurora Jurado ${ }^{1 \dagger}$, María C. Martín ${ }^{2 *+}$, Cristina Abad-Molina ${ }^{3}$, Antonio Orduña ${ }^{3}$, Alba Martínez ${ }^{4}$, Esther Ocaña ${ }^{4}$, Oscar Yarce ${ }^{1}$, Ana M. Navas ${ }^{1}$, Antonio Trujillo ${ }^{1}$, Luis Fernández ${ }^{5}$, Esther Vergara ${ }^{5}$, Beatriz Rodríguez ${ }^{6}$, Bibiana Quirant ${ }^{7}$, Eva Martínez-Cáceres ${ }^{7}$, Manuel Hernández $^{8}$, Janire Perurena-Prieto ${ }^{8}$, Juana Gil $^{9}$, Sergi Cantenys ${ }^{9}$, Gema González-Martínez ${ }^{10}$, María T. Martínez-Saavedra ${ }^{10}$, Ricardo Rojo ${ }^{11}$, Francisco M. Marco ${ }^{12}$, Sergio Mora ${ }^{12}$, Jesús Ontañón ${ }^{13}$, Marcos López-Hoyos ${ }^{14}$, Gonzalo Ocejo-Vinyals ${ }^{14}$, Josefa Melero ${ }^{15}$, Marta Aguilar ${ }^{15}$, Delia Almeida ${ }^{16}$, Silvia Medina ${ }^{16}$, María C. Vegas ${ }^{17}$, Yesenia Jiménez $^{17}$, Álvaro Prada ${ }^{18}$, David Monzón ${ }^{18}$, Francisco Boix ${ }^{19}$, Vanesa Cunill ${ }^{20}$ and Juan Molina ${ }^{1}$

\begin{abstract}
Background: The SARS-CoV-2 infection has widely spread to become the greatest public health challenge to date, the COVID-19 pandemic. Different fatality rates among countries are probably due to non-standardized records being carried out by local health authorities. The Spanish case-fatality rate is $11.22 \%$, far higher than those reported in Asia or by other European countries. A multicentre retrospective study of demographic, clinical, laboratory and immunological features of 584 Spanish COVID-19 hospitalized patients and their outcomes was performed. The use of renin-angiotensin system blockers was also analysed as a risk factor.
\end{abstract}

Results: In this study, $27.4 \%$ of cases presented a mild course, $42.1 \%$ a moderate one and for $30.5 \%$ of cases, the course was severe. Ages ranged from 18 to 98 (average 63). Almost $60 \%$ (59.8\%) of patients were male. Interleukin 6 was higher as severity increased. On the other hand, CD8 lymphocyte count was significantly lower as severity grew and subpopulations CD4, CD8, CD19, and NK showed concordant lowering trends. Severity-related natural killer percent descents were evidenced just within aged cases. A significant severity-related decrease of CD4 lymphocytes was found in males. The use of angiotensin-converting enzyme inhibitors was associated with a better prognosis. The angiotensin II receptor blocker use was associated with a more severe course.

(Continued on next page)

\footnotetext{
* Correspondence: cmartinalo@saludcastillayleon.es

${ }^{\dagger}$ Aurora Jurado and María C. Martín contributed equally to this work.

${ }^{2}$ Centro de Hemoterapia y Hemodonación de Castilla y León, Paseo de Filipinos s/n, 47007 Valladolid, Spain

Full list of author information is available at the end of the article
}

(c) The Author(s). 2020 Open Access This article is licensed under a Creative Commons Attribution 4.0 International License, which permits use, sharing, adaptation, distribution and reproduction in any medium or format, as long as you give appropriate credit to the original author(s) and the source, provide a link to the Creative Commons licence, and indicate if changes were made. The images or other third party material in this article are included in the article's Creative Commons licence, unless indicated otherwise in a credit line to the material. If material is not included in the article's Creative Commons licence and your intended use is not permitted by statutory regulation or exceeds the permitted use, you will need to obtain permission directly from the copyright holder. To view a copy of this licence, visit http://creativecommons.org/licenses/by/4.0/. The Creative Commons Public Domain Dedication waiver (http://creativecommons.org/publicdomain/zero/1.0/) applies to the data made available in this article, unless otherwise stated in a credit line to the data. 


\begin{abstract}
(Continued from previous page)
Conclusions: Age and age-related comorbidities, such as dyslipidaemia, hypertension or diabetes, determined more frequent severe forms of the disease in this study than in previous literature cohorts. Our cases are older than those so far reported and the clinical course of the disease is found to be impaired by age. Immunosenescence might be therefore a suitable explanation for the hampering of immune system effectors. The adaptive immunity would become exhausted and a strong but ineffective and almost deleterious innate response would account for COVID-19 severity. Angiotensin-converting enzyme inhibitors used by hypertensive patients have a protective effect in regards to COVID-19 severity in our series. Conversely, patients on angiotensin II receptor blockers showed a severer disease.
\end{abstract}

Keywords: Severe acute respiratory syndrome coronavirus 2, COVID-19, Immunosenescence, Immunity, Reninangiotensin system, ACE2, Interleukin-6, C-reactive protein, Lymphocytes, Spain

\section{Background}

SARS-CoV-2 infection has become widespread. Never before have we experienced a health emergency like this. At the time of writing, 6 months after the first diagnosed case [1] the virus has infected 12.270 .172 people, with an overall case-fatality rate of $4.52 \%$ [2] far exceeding the $1 \%$ reported outside the epicentre by early studies [3]. It can be traced back to the end of February, when the pandemic started to rapidly expand, hitting some European countries the hardest, such as Spain, with casefatality rates around $11.22 \%$. We lack so far, an explanation to such big differences. They might be related to different local approaches for records and statistics of infected cases in each country. Absolute mortality rates are far higher in Spain than those reported in Asia or other European countries [4].

In 2002, during the SARS-CoV epidemic, a coronavirus was for the first time revealed to be highly pathogenic. Coronaviruses were until then considered to cause just mild infections, mainly in immunocompromised people [5]. SARS-CoV-2 has shown much higher infectivity than SARS-CoV, with a doubling time of 2.33.3 days, and a basic reproductive number $\left(R_{0}\right)$ of 5.7 [6]. SARS-CoV-2 can be considered especially challenging due to its several intrinsic and extrinsic characteristics. It has a highly variable prevalence and outcomes within countries depending on age, weather, and social habits.

The angiotensin-converting enzyme 2 (ACE2) is the receptor for SARS-CoV-2 and plays a key role in human infection [7]. The ACE2 has two isoforms; a large one anchored to the cell membrane [8] and a small soluble isoform lacking anchorage to the membrane and circulates at low concentrations in blood [9]. It has been therefore suggested that the use of drugs increasing ACE2 expression, such as angiotensin-converting enzyme inhibitors (ACEI) and angiotensin II receptor blockers (ARB), could enhance infection [10]. On the other hand, increasing soluble ACE2 may be a therapeutic tool to competitively inhibit the virus [11]. Smoking can cause an increase in ACE2 expression and might, therefore, be a risk factor for SARS CoV2 infection [12].

Both innate and adaptive responses are involved in fighting against SARS-CoV-2 [13]. An accurate immune response is essential for infection resolution. An aberrant immune response might be the key to understanding the immunopathogenesis of SARS-CoV-2 infection. It seems that the progression to severe COVID-19 could be associated with a poor adaptive immune response [14] and with an innate immune response exacerbation, with an increase in plasma levels of both cytokines and pro-inflammatory chemokines [15].

Understanding the pathogenesis of the virus as well as identifying risk or severity factors for COVID-19, are key points for identifying disease evolution biomarkers, and taking immediate preventive actions.

This study aimed to obtain, within the shortest possible time, a reliable snapshot of the demographic and clinical characteristics of COVID-19 patients admitted to Spanish hospitals during the first month of the pandemic and to reveal severity risk factors. This knowledge would help manage both clinical and health decisions.

\section{Results \\ Baseline demographic characteristics, risk factors, and COVID-19 therapies}

A total of 584 SARS-CoV-2 infected inpatients from 19 Spanish Hospitals were included. Twenty-seven percent (27.4\%) of cases presented a mild disease, $42.1 \%$ a moderate one, and $30.5 \%$ a severe one. By data collection deadline, 278 patients have been discharged and 87 have died. The descriptive baseline characteristics of the population (valid $n$, frequencies, percentages, mean, median, standard deviation, and interquartile range) are shown in Table 1. Categorical variables stratified by severity are shown in Table 2 .

Almost $60 \%(59.8 \%)$ of the cases were male. Ages in our cohort ranged from 18 to 98 years old, 63 years old as an average (SD 16.5). Concerning comorbidities, $52.0 \%$ were hypertensive, $78.9 \%$ of them were treated 
Table 1 Baseline characteristics of the study population

\begin{tabular}{|c|c|c|c|c|c|c|}
\hline \multirow{2}{*}{$\begin{array}{l}\text { Clinical and demographic characteristics } \\
\text { Severity }\end{array}$} & \multicolumn{6}{|c|}{ All patients $n=584 ;(\%)$} \\
\hline & & & & & & \\
\hline Mild & \multicolumn{6}{|l|}{$160(27.4)$} \\
\hline Moderate & \multicolumn{6}{|l|}{$246(42.1)$} \\
\hline Severe & \multicolumn{6}{|l|}{$178(30.5)$} \\
\hline \multicolumn{7}{|l|}{ Gender } \\
\hline Male & \multicolumn{6}{|l|}{$349(59.8)$} \\
\hline Female & \multicolumn{6}{|l|}{$235(40.2)$} \\
\hline Hypertension & \multicolumn{6}{|l|}{$293(52.0)$} \\
\hline \multicolumn{7}{|l|}{ RASB ${ }^{\mathrm{a}}$ intake } \\
\hline no & \multicolumn{6}{|l|}{$56(21.1)$} \\
\hline yes & \multicolumn{6}{|l|}{$209(78.9)$} \\
\hline Dyslipidemia & \multicolumn{6}{|l|}{$159(28.8)$} \\
\hline Diabetes & \multicolumn{6}{|l|}{$131(23.7)$} \\
\hline \multirow[t]{2}{*}{ Immunodeficiency (primary or secundary) } & \multicolumn{6}{|l|}{$40(6.8)$} \\
\hline & Ref. $v^{b}$ & $\mathrm{n}$ & Mean & Median & $S D^{c}$ & $I R^{d}$ \\
\hline Age & & 584 & 63.0 & 64.0 & 16.5 & $52-76$ \\
\hline \multicolumn{7}{|l|}{ laboratory data on admission } \\
\hline $1 \mathrm{~L} 6^{\mathrm{e}}(\mathrm{pg} / \mathrm{mL})$ & $<4.4$ & 254 & 113.7 & 41.0 & 355.2 & $15.3-94.6$ \\
\hline $\mathrm{CRP}^{\mathrm{f}}(\mathrm{mg} / \mathrm{L})$ & $<10$ & 523 & 111.30 & 87.00 & 93.70 & 39-153.2 \\
\hline ferritin $(n g / m L)$ & $20-250$ & 297 & 1108.60 & 793.00 & 1524.30 & $361-1417$ \\
\hline D-dimer (ng/mL) & $<500$ & 456 & 1885.10 & 620.00 & 8214.20 & 399-1169 \\
\hline $\mathrm{LDH}^{\mathrm{g}}(\mathrm{U} / \mathrm{L})$ & $120-246$ & 467 & 334.10 & 291.00 & 186.90 & $232-394$ \\
\hline days from onset to admission & & 548 & 7.20 & 7.00 & 5.10 & $4-10$ \\
\hline 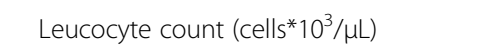 & $4-12.4$ & 570 & 7.57 & 6.39 & 5.60 & $4.82-9.00$ \\
\hline Neutrophil count (cells*103/ $/ \mu \mathrm{L}$ ) & $1.9-8$ & 570 & 5.65 & 4.62 & 3.70 & $3.30-7.12$ \\
\hline 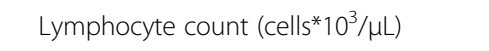 & $0.9-5$ & 570 & 1.16 & 0.99 & 1.06 & $0.71-1.39$ \\
\hline Lymphocyte \% & $19-48$ & 570 & 18.20 & 16.02 & 11.40 & $9.7-23.5$ \\
\hline $\mathrm{CD} 3+\mathrm{CD} 4+\%$ & $25-65$ & 55 & 44.10 & 44.80 & 11.60 & $37-51.3$ \\
\hline $\mathrm{CD} 3+\mathrm{CD} 4+$ count $\left(\right.$ cells $\left.\mathrm{s}^{*} 10^{3} / \mu \mathrm{L}\right)$ & $0.5-1.4$ & 54 & 0.54 & 0.43 & 0.38 & $0.26-0.69$ \\
\hline $\mathrm{CD} 3+\mathrm{CD} 8+\%$ & $12-40$ & 55 & 23.36 & 24.40 & 9.82 & $15.6-30.5$ \\
\hline $\mathrm{CD} 4+\mathrm{CD} 8+$ count $($ cells*103//LL) & $0.25-1$ & 54 & 0.28 & 0.20 & 0.22 & $0.12-0.36$ \\
\hline CD19+ \% & $5-20$ & 52 & 12.90 & 11.55 & 73.00 & $8.2-15.9$ \\
\hline 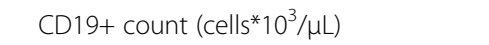 & $0.1-0.5$ & 51 & 0.13 & 0.10 & 0.09 & $0.06-0.20$ \\
\hline Natural Killer \% & $5-20$ & 52 & 15.90 & 15.15 & 8.70 & $8.66-20.65$ \\
\hline Natural Killer count (cells* $10^{3} / \mu \mathrm{L}$ ) & $0.5-5$ & 51 & 0.17 & 0.14 & 0.12 & $0.08-0.20$ \\
\hline Immunoglobulin G & $650-1600$ & 19 & 961.6 & 933.0 & 131.3 & $885-1006$ \\
\hline Immunoglobulin A & $40-350$ & 19 & 230.9 & 223.0 & 72.3 & $178-248$ \\
\hline Immunoglobulin M & $50-300$ & 19 & 103.1 & 90.0 & 39.8 & $72-129$ \\
\hline \multicolumn{7}{|l|}{ Laboratory data at discharge } \\
\hline IL6 (pg/mL) & $<4.4$ & 117 & 99.56 & 9 & 711.81 & $3.9-23.2$ \\
\hline CRP (mg/L) & $<10$ & 297 & 29.96 & 13.00 & 44.90 & $4.7-36$ \\
\hline ferritin (ng/mL) & $20-250$ & 209 & 1263.56 & 633 & 6518.34 & $321-1137$ \\
\hline D- dimer $(\mu \mathrm{g} / \mathrm{L})$ & $<500$ & 271 & 3246.00 & 591 & $33,491.34$ & $360-1149$ \\
\hline LDH (U/L) & $120-246$ & 273 & 342.54 & 234 & 1142.00 & $195-290$ \\
\hline
\end{tabular}


Table 1 Baseline characteristics of the study population (Continued)

\begin{tabular}{|c|c|c|c|c|c|c|}
\hline Clinical and demographic characteristics & All patic & $4 ;(\%)$ & & & & \\
\hline days from admission to discharge & & 146 & 11.75 & 11 & 6.97 & $7-15$ \\
\hline Leucocyte count (cells*103/ $/ \mu \mathrm{L}$ ) & $4-12.4$ & 326 & 7.42 & 6.4 & 3.88 & $4.01-8.40$ \\
\hline 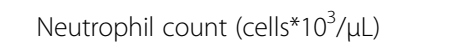 & $1.9-8$ & 326 & 5.17 & 4.1 & 3.79 & $2.98-6.00$ \\
\hline 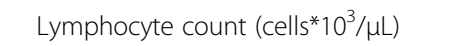 & $0.9-5$ & 326 & 1.51 & 1.44 & 0.76 & $1-1.9$ \\
\hline Lymphocyte \% & $19-48$ & 326 & 23.43 & 23.75 & 11.77 & $14.6-31.1$ \\
\hline $\mathrm{CD} 3+\mathrm{CD} 4+\%$ & $25-65$ & 14 & 48.01 & 53.5 & 15.71 & 49-58.24 \\
\hline $\mathrm{CD} 3+\mathrm{CD} 8+\%$ & $12-40$ & 14 & 19.67 & 18.5 & 10.04 & $10-29.27$ \\
\hline CD19\% & $5-20$ & 14 & 16.97 & 10.93 & 20.32 & 7.9-17 \\
\hline Natural Killers \% & $5-20$ & 14 & 13.02 & 12 & 7.53 & sep-17 \\
\hline
\end{tabular}

Abbreviations: $R A S B^{\mathrm{a}}$ Renin-angiotensin system blockers, Ref. $v^{\mathrm{b}}$ Reference values, $S D^{\mathrm{c}}$ Standard deviation, $I Q R^{\mathrm{d}}$ interquartile range, $I L 6^{\mathrm{e}}$ Interleukin $6, C R P^{\mathrm{f}} C$-reactive protein, $L D H^{\mathrm{g}}$ Lactate dehydrogenase

with blockers of the renin-angiotensin system (RASBs); $28 \% 28.8 \%$ had dyslipidaemia and $23.7 \%$ suffered diabetes. Immunodeficiency was most often secondary to other processes, such as transplantation or chemotherapy treatment. These cases accounted for $6.8 \%(n=40)$ as seen in Table 1.

Hypertension, dyslipidaemia, and diabetes become more frequent with age $(p<0.001)$, (Table 3$)$. These four risk factors showed strong interference (Fig. 1). Nevertheless, a predictive model could not be proposed due to frequent missing values.

Moderate and severe forms were found to be significantly associated with older age, specially over $75(p=$ $0.019 ; \mathrm{OR}=2.179(1.363-3.482))$, male gender $(p<0.001$; OR $=1.929(1.334-2.788))$, dyslipidaemia $(p=0.006$; OR = 2.045 (1.304-3.208)), hypertension $(p=0.015 ; \quad \mathrm{OR}=$ $1.715(1.182-2.486))$ and diabetes $(p=0.003 ; \quad \mathrm{OR}=$ $2.184(1.332-3.583))$. Severe cases over the age of 75 accounted for $37.5 \%$. The use of renin-angiotensin system blockers (RASB) by hypertensive patients revealed no difference regarding mild, moderate, or severe forms of the disease. However, differences arose when considering patients who developed a more serious picture compared to those who had a mild-moderate course. Intake of RASB showed again no effect regarding COVID19 severity. Meanwhile, when assessing the use of single RASBs, the intake of ACEI was associated with a better prognosis $((p=0.046$; Odds Ratio for severe COVID-19 was 0.56 with a $95 \%$ Confidence Interval (0.31-0.99)). On the contrary, the use of ARB was related to higher severity (p 0.004; Odds Ratio for severe COVID-19 was 2.26 with 95\% Confidence Interval (1.29-3.96)) (Table 2).

Once at hospital, $84.2 \%$ of inpatients received antibiotics; the most commonly prescribed ones were azithromycin combinations (71.3\%); those treated with antimalarial drugs accounted for 71.7 and $65.8 \%$ received antivirals, being lopinavir/ritonavir being the most widely used. Around one-half of cases (50.2\%), received combined therapy consisting of antibiotics, antimalarials, and antivirals (commonly named triple therapy). Immunosuppressant drugs were used in $18.3 \%$ of cases. Anti-cytokine therapy was used in $8.4 \%$, mostly anti-IL6R (Tocilizumab), and $17.3 \%$ were treated with either $\alpha$ or $\beta$ interferon.

\section{Laboratory parameters on admission and at discharge}

On admission, means of laboratory parameters, IL-6, CRP, ferritin, D-dimer, LDH, leukocyte, and neutrophil counts, were above usual reference ranges (those ranges can slightly change within centres), in contrast to lymphocyte counts and percentages as well as lymphocyte subset counts, that are within the lower part of their ranges (Table 1). Higher severity was significantly associated with higher levels of IL-6, CRP, ferritin, D-dimer, LDH, leukocyte, and neutrophil counts, but with lower lymphocyte percentages and counts (Table 4). The mean percentages of lymphocyte subpopulations $(n=54)$ were within normal ranges. CD8 Lymphocyte count was found to be significantly higher in mild cases, similar trends were found for CD4, CD19, and NK cell counts. IgG and IgM values were as well inversely related to severity (Table 4).

At discharge, IL-6, ferritin, D-dimer, LDH, leukocyte, and neutrophil counts remained significantly higher regarding severe cases compared to mild or moderate ones, opposite to lymphocyte percentage (Table 4). CRP values at discharge were close to normal ranges regardless of severity. When comparing laboratory data at discharge with those on admission, an overall return to reference ranges of most parameters was observed, with significantly lower mean values of IL-6, CRP, and LDH, as well as higher mean values of leukocyte counts, neutrophil counts, and lymphocyte counts and percentages. D-dimer and ferritin still remained high or became even higher values upon arrival (Table 4).

Most of the differences in parameter levels amongst the severity groups were the same regardless of age (Fig. 2). It could be evidenced that lymphopenia and increased IL-6 
Table 2 Age, gender, comorbidities and RASB intake relationship with COVID-19 severity

\begin{tabular}{|c|c|c|c|}
\hline & Mild & Moderate & Severe \\
\hline Age $(p=0.019)$ & n (\%) & n (\%) & n (\%) \\
\hline$<30$ & $10(43.5)$ & $9(39.1)$ & $4(17.4)$ \\
\hline $30-45$ & $26(37.7)$ & $26(37.7)$ & $17(24.6)$ \\
\hline $45-60$ & $41(26.6)$ & $62(40.3)$ & $51(33.1)$ \\
\hline $60-75$ & 57 (30.6) & $80(43.0)$ & $49(26.3)$ \\
\hline$>75$ & $26(17.1)$ & $69(45.4)$ & $57(37.5)$ \\
\hline \multicolumn{4}{|c|}{ Gender $(p<0.001)$} \\
\hline Male & $77(22.1)$ & $144(41.3)$ & $128(36.7)$ \\
\hline Female & $83(35.3)$ & $102(43.4)$ & $50(21.3)$ \\
\hline \multicolumn{4}{|c|}{ Hypertension $(p=0.015)$} \\
\hline No & $91(33.7)$ & $107(39.6)$ & $72(26.7)$ \\
\hline Yes & $67(22.9)$ & $132(45.1)$ & $94(32.1)$ \\
\hline \multicolumn{4}{|c|}{ Dyslipidemia $(p=0.006)$} \\
\hline No & $127(32.2)$ & $159(40.4)$ & $108(27.4)$ \\
\hline Yes & $30(18.9)$ & $75(47.2)$ & $54(34.0)$ \\
\hline \multicolumn{4}{|c|}{ Diabetes $(p=0.003)$} \\
\hline No & $134(31.8)$ & $175(41.5)$ & $113(26.8)$ \\
\hline Yes & $23(17.6)$ & $59(45.0)$ & 49 (37.4) \\
\hline \multicolumn{4}{|c|}{ Immunodeficiency } \\
\hline No & $283(60.6)$ & $379(81.0)$ & $273(58.4)$ \\
\hline Yes & $8(68.4)$ & $21(102.6)$ & $11(28.9)$ \\
\hline \multicolumn{4}{|l|}{ RASB $^{\mathrm{a}}$ intake } \\
\hline No & $10(17.9)$ & $32(57.1)$ & $14(25.0)$ \\
\hline \multirow[t]{2}{*}{ Yes } & $50(23.9)$ & $91(43.5)$ & $68(34.0)$ \\
\hline & Mild-Moderate & Severe & \\
\hline RASB $^{\mathrm{a}}$ intake & n (\%) & n (\%) & \\
\hline No & $42(75)$ & $14(25)$ & \\
\hline Yes & $142(67.9)$ & $67(32.1)$ & \\
\hline \multicolumn{4}{|c|}{ ACE $^{\mathrm{b}}$ intake $(p=0.046)$} \\
\hline No & $111(65.3)$ & $59(34.7)$ & \\
\hline Yes & $71(77.2)$ & $21(22.8)$ & \\
\hline \multicolumn{4}{|c|}{ ARB $^{c}$ intake $(p=0.004)$} \\
\hline No & $95(77.9)$ & $27(22.1)$ & \\
\hline Yes & $76(60.8)$ & $49(39.2)$ & \\
\hline
\end{tabular}

Abbreviations: $p$ Chi Squared $\mathrm{p}$-values, $R A S B^{\mathrm{a}}$ Renin-angiotensin system blockers, $A C E^{b}$ Angiotensin-converting enzyme inhibitors, $A R B^{\mathrm{C}}$ Angiotensin II receptor blockers

were significant regardless of severity in all age groups but in patients under 30. CD8 population differences (both considering absolute count and percentage) were significant only within the 45-60 group (the largest one). The lymphocyte count decrease, which was seen globally, was only evidenced for $30-45$ and $45-60$ age ranges. NK percentage was higher in milder cases within older individuals (60-75). Severity-related decreases of IgM $(p=0.027)$, CD4 ( $\mathrm{p} 0.007)$ and CD8 (p 0.008) lymphocytes were evidenced just in males (Fig. 3).

\section{Discussion}

The COVID-19 pandemic became particularly virulent in Mediterranean countries such as Spain, both in terms of the number of affected people and the fatalities. This is the first report on Spanish COVID-19 inpatients; our aim was to outline illness demographic features, risk factors, and laboratory parameters, in relationship to disease severity. In our series, $27.4 \%$ of patients showed a mild course, $42.1 \%$ a moderate course, and $30.5 \%$ a severe one. Several works analyse severity in COVID-19 inpatients, almost all from Chinese hospitals. Those, including two multicentre studies, can be told to have a low severity profile in which severe cases ranged from 16 to $26 \%$ [16-19], except for the study of Zhou et al. [20], where critical cases reached $28 \%$.

It has been reported elsewhere that older patients or those with at least one previous comorbidity have a worse prognosis [16, 19-21]. There is, however, remarkable heterogeneity regarding these studies. The ages of the patients in our series were much higher than those previously published, with an average of 63 years. They can be found in literature, average cohort ages ranging from 36 to 58 years old [16-20, 22-24]. However, Grasselli et al. [25], in a multicentre Italian study focusing on patients admitted to the ICU, reports an average age of 63 , similar to ours. In SARS-CoV-2 infection, the number of paediatric patients compared to adults is lower, with milder symptoms and better prognoses [26]. This fact highlights a possible immunosenescence effect on the evolution of the disease [27]. Immunosenescence refers to the age-associated decline of the immune system [28]. Immunosenescence is associated with adaptive immune changes and (less studied) in the innate immune system. These changes within $\mathrm{B}$ and $\mathrm{T}$ cell compartments do not affect the number of circulating lymphocytes but their repertoire and functionality. Immunosenescence processes include: decreased production of naïve lymphocytes, lymphocyte contracted repertoire, decreased proliferative and functional capacity of effector lymphocytes, increased population of memory lymphocytes, fibrotic changes in lymph node architecture, and cytokine production dysregulation. These phenomena result in a lower vaccination response and a greater infection susceptibility; thus, the infections often evolve more severely. More than $70 \%$ of influenza mortality occurs in people over 65 years and the RSV mortality rate within the elderly population is $18 \%$ [29]. Knowledge of the mechanisms behind these changes is crucial for vaccine development and for keeping the elderly safe. People over 60 accounts for $11 \%$ of the 
Table 3 Influence of age and gender on comorbidities

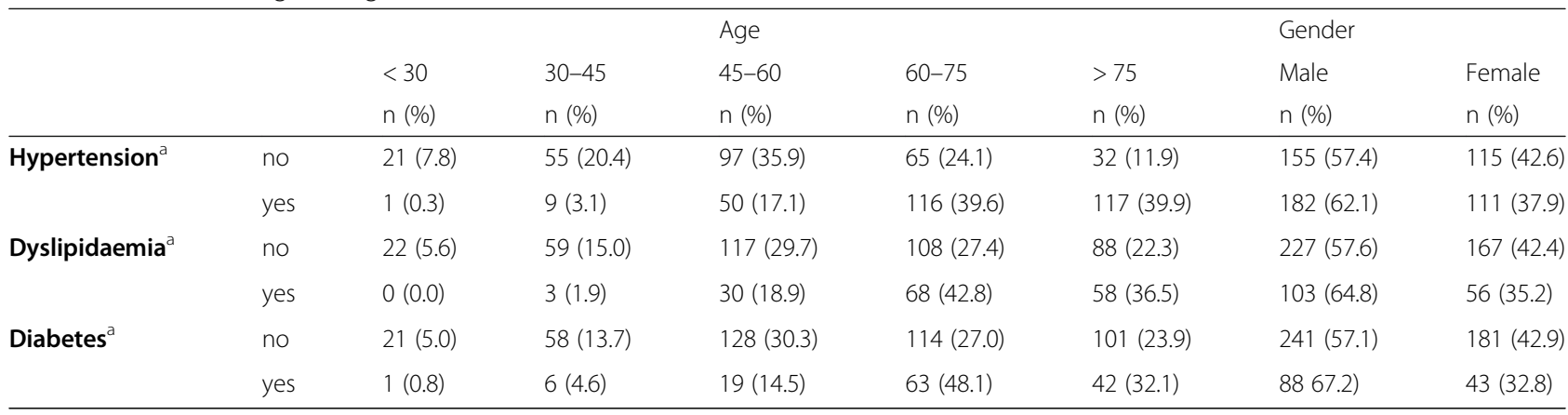

all Chi Squared p-values either vs age or gender were $<0.001$

worldwide population and they are expected to reach $22 \%$ by 2050 [28]. In Spain, $19.4 \%$ of the population is over the age of 65 to date [30]. In our series, $18.15 \%$ of the cases were people aged 60 or above.

Possibly due to ageing, frequencies for comorbidities such as hypertension or diabetes were higher in our series than those reported in previous studies $[16,17$, 19-24, 31] and the prevalence of diabetes was greater than that recorded in the Spanish adult population $(23.7 \%$ vs. $13.8 \%)$ [32]. Notwithstanding, the prevalence of hypertension mirrored that of the general adult

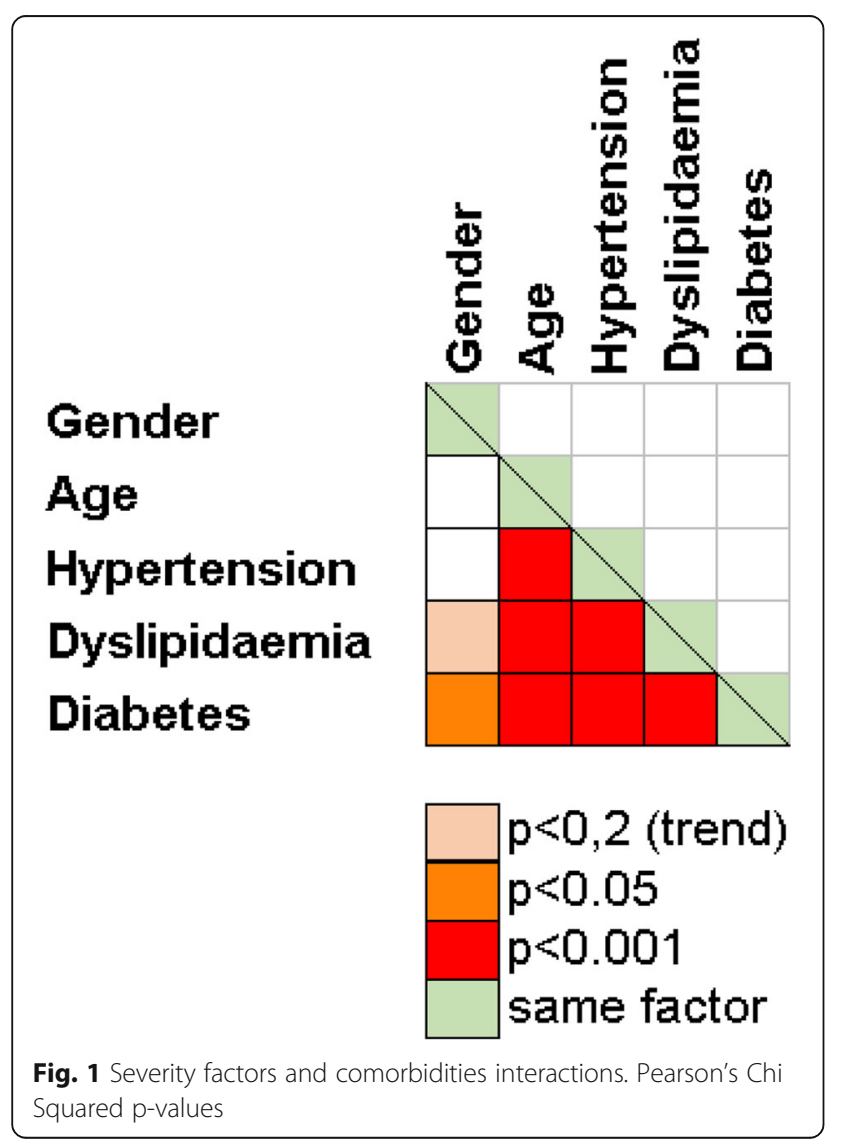

Spanish population (overall, 42.6\%; people over 60, 75.4\%) [33]. Not only SARS-CoV-2, but most human coronaviruses strike the elderly and individuals with underlying comorbidities harder [34].

As in previous studies, cases were more often males $[19,20,22,24]$. This fact is noteworthy, considering that men account only for $41.7 \%$ of the Spanish population over 50 years old [30] (59.8\% in our COVID-19 cohort). Besides, the male gender was found to be associated with severity. In an Italian report of patients admitted to the ICU, up to $80 \%$ of the cases were males [25]. This fact would be in line with our observed effect of gender on severity.

Concerning laboratory parameters, our findings were comparable to those reported in previous studies, with elevations of acute phase reactants (CRP, D-dimer, LDH, ferritin) increasing with severity and decreasing when the evolution of patients was favourable [19, 20, 22, 31]. Particularly striking was the change of the CRP, which was almost within its reference range at discharge.

Several publications have focused on immunological markers in COVID-19 [19, 20, 31]. The extensive work of Diao et al. [14] analyses the secretory profile of inflammatory cytokines, lymphocyte populations, and their relationship to disease severity in 499 patients. The authors find an increase in pro-inflammatory cytokines inversely correlated to T-lymphocyte populations. This immune profile was also related to the severity of the disease. CD4, CD8, and IL-6 are reported to covariate at least in mild cases [35]. Data in our series would ratify their findings, therefore, an increase in IL-6 and a decrease in both total lymphocytes and lymphocyte populations could be seen. Once again, these changes were greater the more severe the condition. In our cohort, all lymphocyte subset counts CD4, CD8, CD19, and NK were below reference ranges upon arrival and were strongly decreased in severe cases, despite the differences being only significant for the CD8 population regarding overall data. Lymphopenia has been described in other infectious contexts such as sepsis, HIV, SARS, and MERS infections, [36, 37]. The underlying cause of 
Table 4 Age and Laboratory results. Association to COVID-19 severity and evolution from admission to discharge

\begin{tabular}{|c|c|c|c|c|c|c|c|}
\hline & Severity $p$-value & $\Delta$ a-d ${ }^{a} p$-value & $n$ & mean & median & $S D^{b}$ & $\mathrm{IQR}^{\mathrm{C}}$ \\
\hline Age & $<0.001(\mathrm{~A})$ & & & & & & \\
\hline Mild & & & 160 & 58.96 & 61.00 & 17.08 & $49-70.5$ \\
\hline Moderate & & & 246 & 64.08 & 66.00 & 16.05 & $54-77$ \\
\hline Severe & & & 178 & 65.25 & 65.50 & 15.98 & $54-79$ \\
\hline \multicolumn{8}{|l|}{ On admission } \\
\hline $\mathrm{IL} 6^{\mathrm{d}}(\mathrm{pg} / \mathrm{mL})$ & $<0.001$ & & & & & & \\
\hline Mild & & & 78 & 31.40 & 17.60 & 40.53 & $9-40.9$ \\
\hline Moderate & & & 98 & 77.86 & 43.10 & 155.30 & $19.5-87.3$ \\
\hline Severe & & & 78 & 241.16 & 87.45 & 597.92 & $30.4-239.7$ \\
\hline $\mathrm{CRP}^{\mathrm{e}}(\mathrm{mg} / \mathrm{L})$ & $<0.001$ & & & & & & \\
\hline Mild & & & 132 & 66.21 & 44.45 & 67.83 & $17.45-85.2$ \\
\hline Moderate & & & 231 & 108.82 & 93.00 & 83.25 & $43.8-147$ \\
\hline Severe & & & 160 & 152.14 & 128.40 & 107.91 & $64.25-217.65$ \\
\hline ferritin (ng/mL) & $<0.001$ & & & & & & \\
\hline Mild & & & 80 & 711.39 & 491.45 & 881.96 & $201.65-874$ \\
\hline Moderate & & & 133 & 1003.30 & 775.00 & 902.63 & $390-1479$ \\
\hline Severe & & & 84 & 1653.65 & 1073.50 & 2404.04 & 713.5-1796.5 \\
\hline D-dimer (ng/mL) & $<0.001$ & & & & & & \\
\hline Mild & & & 120 & 1083.58 & 522.00 & 3684.33 & $340.5-797$ \\
\hline Moderate & & & 200 & 1442.13 & 594.00 & 3878.02 & $391.5-1025$ \\
\hline Severe & & & 136 & 3243.72 & 960.50 & $13,804.06$ & $468.5-1586$ \\
\hline $\mathrm{LDH}^{\mathrm{f}}(\mathrm{U} / \mathrm{L})$ & $<0.001$ & & & & & & \\
\hline Mild & & & 124 & 252.55 & 244.50 & 75.01 & $200-292.5$ \\
\hline Moderate & & & 208 & 314.61 & 292.50 & 123.08 & $240-372.5$ \\
\hline Severe & & & 135 & 438.99 & 401.00 & 274.08 & $279-524$ \\
\hline 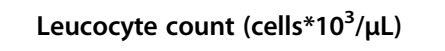 & $<0.001$ & & & & & & \\
\hline Mild & & & 147 & 6.25 & 5.70 & 2.46 & $4.68-7.03$ \\
\hline Moderate & & & 246 & 7.60 & 6.15 & 7.16 & $4.70-8.82$ \\
\hline Severe & & & 177 & 8.65 & 7.89 & 4.73 & $5.50-10.3$ \\
\hline Neutrophil count (cells $\left.{ }^{*} 10^{3} / \mu \mathrm{L}\right)$ & $<0.001$ & & & & & & \\
\hline Mild & & & 147 & 4.33 & 3.89 & 2.22 & $3.00-5.17$ \\
\hline Moderate & & & 246 & 5.39 & 4.32 & 3.74 & $3.20-7.00$ \\
\hline Severe & & & 177 & 7.10 & 6.40 & 4.13 & $4.30-8.71$ \\
\hline Lymphocyte count (cells*103/uL) & 0.048 & & & & & & \\
\hline Mild & & & 147 & 1.29 & 1.10 & 0.76 & $0.86-1.57$ \\
\hline Moderate & & & 246 & 1.13 & 0.97 & 0.85 & $0.73-1.33$ \\
\hline Severe & & & 177 & 1.10 & 0.90 & 1.47 & $0.59-1.24$ \\
\hline Lymphocyte \% & $<0.001$ & & & & & & \\
\hline Mild & & & 147 & 22.04 & 19.70 & 11.14 & $14.7-28.7$ \\
\hline Moderate & & & 246 & 18.55 & 17.10 & 10.99 & $9.8-24.5$ \\
\hline Severe & & & 177 & 14.64 & 12.00 & 11.01 & $7.5-18.1$ \\
\hline \multicolumn{8}{|l|}{$\mathrm{CD} 3+\mathrm{CD} 4+\%$} \\
\hline Mild & & & 8 & 41.31 & 41.10 & 6.56 & $36-47.1$ \\
\hline Moderate & & & 35 & 45.84 & 46.50 & 12.52 & $38.3-52.8$ \\
\hline
\end{tabular}


Table 4 Age and Laboratory results. Association to COVID-19 severity and evolution from admission to discharge (Continued)

\begin{tabular}{|c|c|c|c|c|c|c|c|}
\hline & Severity $p$-value & $\Delta a-d^{a} p$-value & $\mathrm{n}$ & mean & median & $S D^{b}$ & $\mathrm{IQR}^{\mathrm{C}}$ \\
\hline Severe & & & 12 & 41.04 & 41.90 & 11.25 & $34.3-50.4$ \\
\hline \multicolumn{8}{|l|}{ CD3 + CD4+ count (cells* $\left.10^{3} / \mu \mathrm{L}\right)$} \\
\hline Mild & & & 8 & 0.74 & 0.71 & 0.46 & $0.32 .35-1.1$ \\
\hline Moderate & & & 33 & 0.56 & 0.44 & 0.39 & $0.27-0.69$ \\
\hline Severe & & & 13 & 0.36 & 0.32 & 0.20 & $0.27-0.46$ \\
\hline \multicolumn{8}{|l|}{$\mathrm{CD} 3+\mathrm{CD} 8+\%$} \\
\hline Mild & & & 8 & 26.23 & 27.00 & 4.26 & $22.7-28.9$ \\
\hline Moderate & & & 35 & 21.74 & 20.30 & 10.66 & $12.09-30.5$ \\
\hline Severe & & & 12 & 26.57 & 28.30 & 9.18 & 19.39-32.4 \\
\hline CD4 + CD8+ count (cells*10 $10^{3} / \mu \mathrm{L}$ ) & $0.041(\mathrm{~A})$ & & & & & & \\
\hline Mild & & & 8 & 0.45 & 0.41 & 0.28 & $0.20-0.70$ \\
\hline Moderate & & & 33 & 0.25 & 0.18 & 0.20 & $0.13-0.35$ \\
\hline Severe & & & 13 & 0.24 & 0.24 & 0.18 & $0.084-0.30$ \\
\hline \multicolumn{8}{|l|}{ CD19+ \% } \\
\hline Mild & & & 8 & 11.50 & 10.90 & 3.36 & $8.95-13$ \\
\hline Moderate & & & 35 & 12.47 & 10.60 & 6.99 & $7.3-16$ \\
\hline Severe & & & 9 & 15.97 & 12.00 & 10.61 & $10.3-14.83$ \\
\hline \multicolumn{8}{|l|}{ CD19+ count (cells*103/ $/ \mu \mathrm{L}$ ) } \\
\hline Mild & & & 8 & 0.19 & 0.18 & 0.11 & $0.09-0.29$ \\
\hline Moderate & & & 33 & 0.12 & 0.09 & 0.09 & $0.06-0.20$ \\
\hline Severe & & & 10 & 0.16 & 0.10 & 0.08 & $0.06-0.12$ \\
\hline \multicolumn{8}{|l|}{ Natural Killer \% } \\
\hline Mild & & & 8 & 15.59 & 13.80 & 8.96 & $8.55-23.55$ \\
\hline Moderate & & & 35 & 16.06 & 15.50 & 8.36 & $11.8-20.7$ \\
\hline Severe & & & 9 & 15.67 & 11.40 & 10.90 & $6.8-20.6$ \\
\hline \multicolumn{8}{|l|}{ Natural Killer count (cells*10 $0^{3} / \mu \mathrm{L}$ ) } \\
\hline Mild & & & 8 & 0.23 & 0.16 & 0.15 & $0.12-0.37$ \\
\hline Moderate & & & 33 & 0.17 & 0.16 & 0.12 & $0.08-0.21$ \\
\hline Severe & & & 10 & 0.11 & 0.12 & 0.06 & $0.09-0.14$ \\
\hline $\lg G(\mathrm{mg} / \mathrm{dL})$ & 0.048 & & & & & & \\
\hline Mild & & & 1 & 1006.00 & 1006.00 & & $1006-1006$ \\
\hline Moderate & & & 13 & 998.31 & 934.00 & 133.23 & $915-1071$ \\
\hline Severe & & & 5 & 857.20 & 862.00 & 76.43 & 788-885 \\
\hline \multicolumn{8}{|l|}{$\lg A(m g / d L)$} \\
\hline Mild & & & 1 & 248.00 & 248.00 & . & $248-248$ \\
\hline Moderate & & & 13 & 234.00 & 223.00 & 86.48 & $175-248$ \\
\hline Severe & & & 5 & 219.40 & 218.00 & 28.98 & $213-230$ \\
\hline $\lg M(\mathrm{mg} / \mathrm{dL})$ & 0.009 & & & & & & \\
\hline Mild & & & 1 & 129.00 & 129.00 & & $129-129$ \\
\hline Moderate & & & 13 & 118.00 & 121.00 & 34.88 & $88-141$ \\
\hline Severe & & & 5 & 59.20 & 58.00 & 13.83 & $50-72$ \\
\hline \multicolumn{8}{|l|}{ At discharge } \\
\hline IL6 (pg/mL) & 0.017 & & & & & & \\
\hline Mild & & & 55 & 21.17 & 11.60 & 28.51 & $4.77-23.2$ \\
\hline
\end{tabular}


Table 4 Age and Laboratory results. Association to COVID-19 severity and evolution from admission to discharge (Continued)

\begin{tabular}{|c|c|c|c|c|c|c|c|}
\hline & Severity $p$-value & $\Delta a-d^{a} p$-value & $n$ & mean & median & $S D^{b}$ & $\mathrm{IQR}^{\mathrm{C}}$ \\
\hline Moderate & & $<0.001$ & 50 & 47.04 & 7.26 & 126.46 & $1.88-13.4$ \\
\hline Severe & & & 12 & 677.75 & 24.86 & 2204.56 & $9.1-59.63$ \\
\hline CRP (mg/L) & & $<0.001$ & & & & & \\
\hline Mild & & & 115 & 27.69 & 14.30 & 32.92 & $6.3-38.1$ \\
\hline Moderate & & & 137 & 29.93 & 13.93 & 42.69 & $4-36$ \\
\hline Severe & & & 45 & 35.86 & 8.00 & 71.26 & $4-25.2$ \\
\hline ferritin (ng/mL) & $<0.001$ & & & & & & \\
\hline Mild & & & 77 & 611.96 & 386.00 & 646.97 & $245-793$ \\
\hline Moderate & & & 94 & 778.67 & 687.50 & 599.84 & $331-1178$ \\
\hline Severe & & & 38 & 3783.41 & 1085.90 & $15,135.72$ & $571-1776$ \\
\hline D-dimer (ng/mL) & $<0.001$ & & & & & & \\
\hline Mild & & & 94 & 705.22 & 463.50 & 937.24 & $326-751$ \\
\hline Moderate & & & 130 & 5219.08 & 586.00 & $48,290.67$ & $356-1040$ \\
\hline Severe & & $<0.001$ & 47 & 2870.13 & 1415.00 & 4230.08 & 792-3912 \\
\hline LDH (U/L) & $<0.001$ & 0.004 & & & & & \\
\hline Mild & & & 102 & 238.22 & 218.00 & 78.79 & $192-261$ \\
\hline Moderate & & & 124 & 247.19 & 235.50 & 83.32 & $192-271$ \\
\hline Severe & & & 47 & 820.53 & 286.00 & 2722.15 & $242-400$ \\
\hline 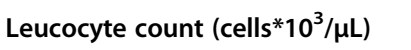 & $<0.001$ & 0.013 & & & & & \\
\hline Mild & & & 127 & 6.26 & 5.80 & 2.59 & $4.78-7.21$ \\
\hline Moderate & & & 146 & 7.46 & 6.90 & 3.08 & $5.30-9.20$ \\
\hline Severe & & & 53 & 10.10 & 8.31 & 6.41 & $5.79-12.33$ \\
\hline Neutrophil count (cells*10 $10^{3} / \mu \mathrm{L}$ ) & $<0.001$ & & & & & & \\
\hline Mild & & $<0.001$ & 127 & 4.12 & 3.54 & 2.56 & $2.67-4.50$ \\
\hline Moderate & & & 146 & 5.07 & 4.40 & 2.99 & $3.09-6.20$ \\
\hline Severe & & & 53 & 8.01 & 6.50 & 6.18 & $3.78-9.60$ \\
\hline Lymphocyte count (cells* $10^{3} / \mu \mathrm{L}$ ) & & $<0.001$ & & & & & \\
\hline Mild & & & 127 & 1.50 & 1.45 & 0.62 & $1.06-1.89$ \\
\hline Moderate & & & 146 & 1.54 & 1.40 & 0.87 & $0.97-1.87$ \\
\hline Severe & & & 53 & 1.52 & 1.54 & 0.77 & $0.8-2.02$ \\
\hline Lymphocyte \% & 0.006 & 0.007 & & & & & \\
\hline Mild & & & 127 & 25.47 & 26.10 & 9.31 & $19.4-32.1$ \\
\hline Moderate & & & 146 & 23.12 & 22.65 & 12.73 & $13.7-30.3$ \\
\hline Severe & & & 53 & 19.41 & 18.40 & 13.34 & $8.6-26.6$ \\
\hline \multicolumn{8}{|l|}{$\mathrm{CD} 3+\mathrm{CD} 4+\%$} \\
\hline Mild & & & 3 & 49.33 & 54.00 & 13.61 & $34-60$ \\
\hline Moderate & & & 11 & 47.66 & 53.00 & 16.84 & $49-58.24$ \\
\hline Severe & & & 0 & & & & \\
\hline \multicolumn{8}{|l|}{$\mathrm{CD} 3+\mathrm{CD} 8+\%$} \\
\hline Mild & & & 3 & 20.33 & 20.00 & 11.50 & $9-32$ \\
\hline Moderate & & & 11 & 19.50 & 17.00 & 10.22 & $10-29.27$ \\
\hline Severe & & & 0 & & & & \\
\hline \multicolumn{8}{|l|}{ CD19\% } \\
\hline Mild & & & 3 & 15.00 & 17.00 & 6.24 & $8-20$ \\
\hline
\end{tabular}


Table 4 Age and Laboratory results. Association to COVID-19 severity and evolution from admission to discharge (Continued)

\begin{tabular}{|c|c|c|c|c|c|c|c|}
\hline & Severity $p$-value & $\Delta a-d^{a} p$-value & $\mathrm{n}$ & mean & median & $S D^{b}$ & $\mathrm{IQR}^{\mathrm{C}}$ \\
\hline Moderate & & & 11 & 17.51 & 10.86 & 22.97 & $7-15$ \\
\hline Severe & & & 0 & & & & \\
\hline \multicolumn{8}{|c|}{ Natural Killer \% } \\
\hline Mild & & & 3 & 13.67 & 15.00 & 4.16 & $9-17$ \\
\hline Moderate & & & 11 & 12.85 & 11.00 & 8.38 & $7-17.3$ \\
\hline Severe & & & 0 & & & & \\
\hline
\end{tabular}

Abbreviations: Severity $p$-values come from Kruskal-Wallis median test unless (A) marked, those $p$ values come from One-Way ANOVA so far the parameter follows a normal distribution and its $\mathrm{n}>30: \Delta \mathrm{a}-\mathrm{d}^{\mathrm{a}}$, differences between admission and discharge (Wilcoxons' test for paired samples $\mathrm{p}$-values); $S D^{\mathrm{b}}$ Standard deviation, $I Q R^{\mathrm{c}}$ Interquartile range, $I L \sigma^{\mathrm{d}}$ Interleukin $6, C R P^{\mathrm{e}}$ C-reactive protein, $L D H^{\mathrm{f}}$ Lactate dehydrogenase

lymphopenia in severe cases of COVID-19 is still unknown and several mechanisms have been proposed to explain it. Some of these hypotheses are apoptosis of $\mathrm{T}$ lymphocytes [38], an IL-induced pyroptosis-1 $\beta$ [38], a direct cytopathic virus action on $\mathrm{T}$ lymphocyte [39], a bone marrow suppression due to cytokine storm (similar to that in sepsis), or pulmonary sequestration by bilateral pneumonia [40]. Quantitative alterations in the effectors of the immune system such as lymphopenia and increased levels of IL-6, together with possible qualitative alterations associated with the ageing of the immune system, could act synergistically, causing a more serious condition.

Since the seminal publication of Lei Fang et al. on the possible involvement of renin-angiotensin system blockers in SARS-CoV-2 infection [10] just 3 months ago, there has been a lot of controversy about it. No sooner had the scientific community realised its foreseeable impact, they began to take sides both for and against the hypothesis [41-44]. ACE2 molecules are the door used by SARS-CoV-2 to enter the cell [45]. RASBs indirectly increase the expression and secretion to the extracellular medium of ACE2 in various cell types, including airway alveolar epithelial cells [41]. RASBs might therefore facilitate the entrance of the virus or prevent it [42]. Additionally, the expression of ACE2 is associated with positive effects on lung homeostasis, which could be beneficial for tissue recovery from the damage caused by the SARS-CoV-2 infection [11, 42]. ACE2 expression is reported to be related to age and sex. It is high in children and would be high in young women, decreasing with ageing, and correlated negatively with chronic disease comorbidities such as hypertension [46]. ACE2 levels will inversely correlate COVID-19 severity and poor outcomes. Most literature for or against the role of the use of RASB consists mainly of theoretical positioning based on the knowledge of the physiological properties of these drugs. There is a limited number of original studies analysing the RASB intake effect on COVID-19.
In our series, 293 patients were hypertensive. From these, 265 had records of being on anti-hypertensive drugs in their clinical history; of the latest, 209 were on RASB (78.86\%; this feature is similar to the reported overall intake of these drugs by the Spanish hypertensive population [33]. No differences in severity concerning the use of RASB were found. Notwithstanding, when RASB were separately analysed, ARBs were found to be associated with a worse course of the disease ( $p$ 0.004) and ACEI with a better evolution (p 0.046). A lack of association between the use of RASB and severity has been previously reported by several authors. Tedeschi et al. [47], to elucidate whether RASB treatment had an impact on COVID-19 mortality, analyse 311 hypertensive patients hospitalized in 10 Italian centres. A multivariate Cox regression analysis of intra-hospital mortality shows that the use of RASBs is not associated with outcome. A large population-based case-control study by Mancia et al. [48] including 6272 hypertensive patients with COVID-19 disease has just been published, where the RASBs intake effect on COVID-19 is analysed. They conclude that neither susceptibility nor disease severity is associated with RASB intake. Even more, Chen et al. [31] report about 113 hypertensive patients, 33 (29.2\%) of them were on RASB treatment, $87.9 \%$ of whom had moderate disease, and $12.2 \%$ a severe or critical COVID19. Nevertheless, in contrast with our results, when Mancia et al. separately address the ACEI and ARB effects on the severity, they conclude that neither ACEI nor ARB show an independent association with COVID19 severity. This difference might be due to the structure of the cohorts. It shall be noticed that all patients in our series were cases hospitalized. Even those here so categorized as having a mild course required hospitalization. Another main difference is related to the criteria used to define when a patient was on therapy with antihypertensive drugs. In our series, any intakes by disease onset were considered, whereas, in the mentioned study, even the whole preceding year was considered. Hence, these 


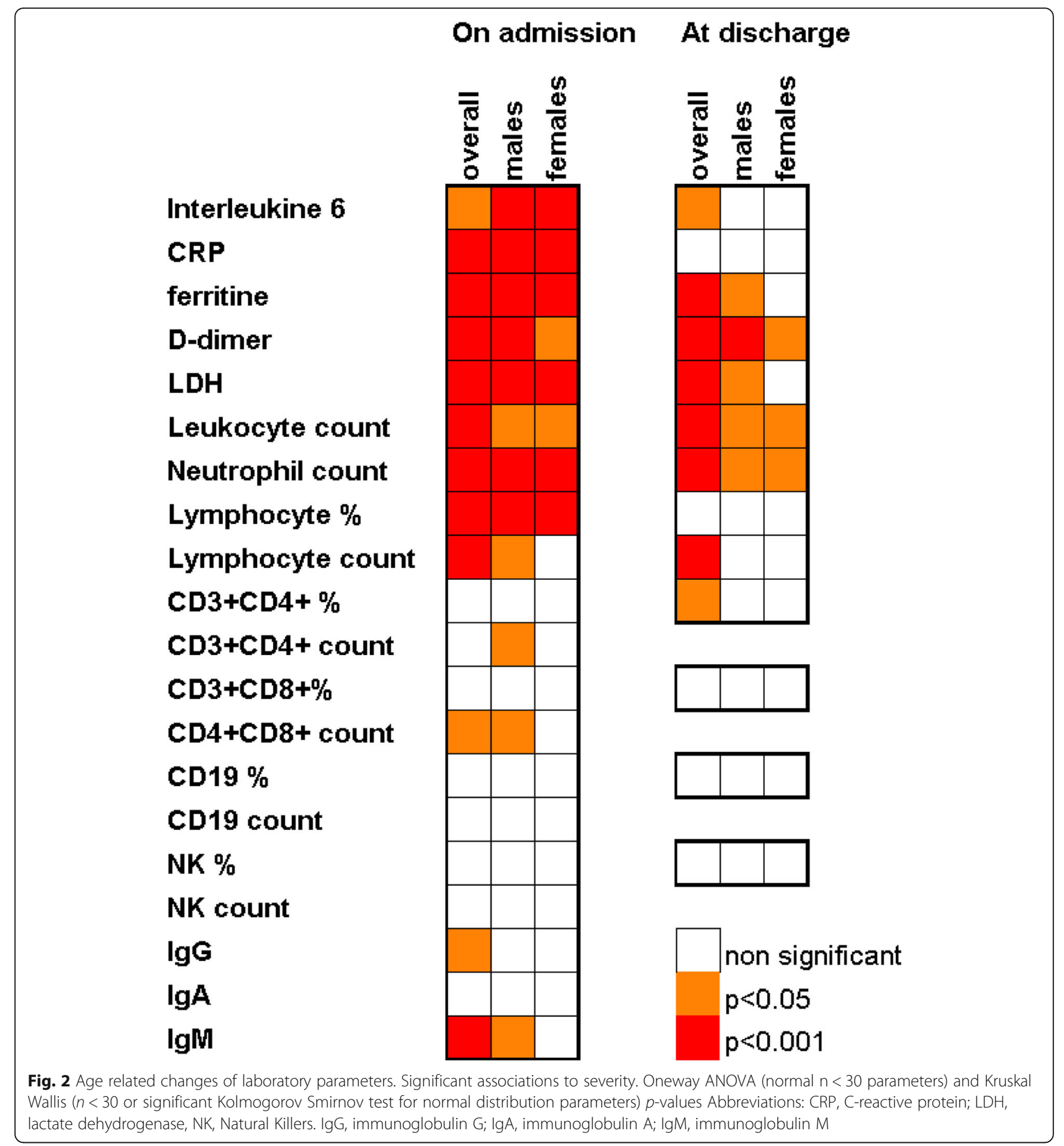

differences indicate that further studies to clarify the possible roles of various types of RASB in COVID-19 prognosis are warranted.

The present study has two major limitations. The first one is derived from its retrospective design. As we are reporting on the very first cases of the disease in Spain, several immunological parameters and risk factors of interest were not systematically tested or recorded into medical history. The other restraint is the short followup period of patients, which limits the possibility of having a complete follow up of those who were still in hospital by the data collection deadline.

\section{Conclusions}

Age has emerged as a crucial factor in our series. Age is also one of the major determinants for all other COVID- 


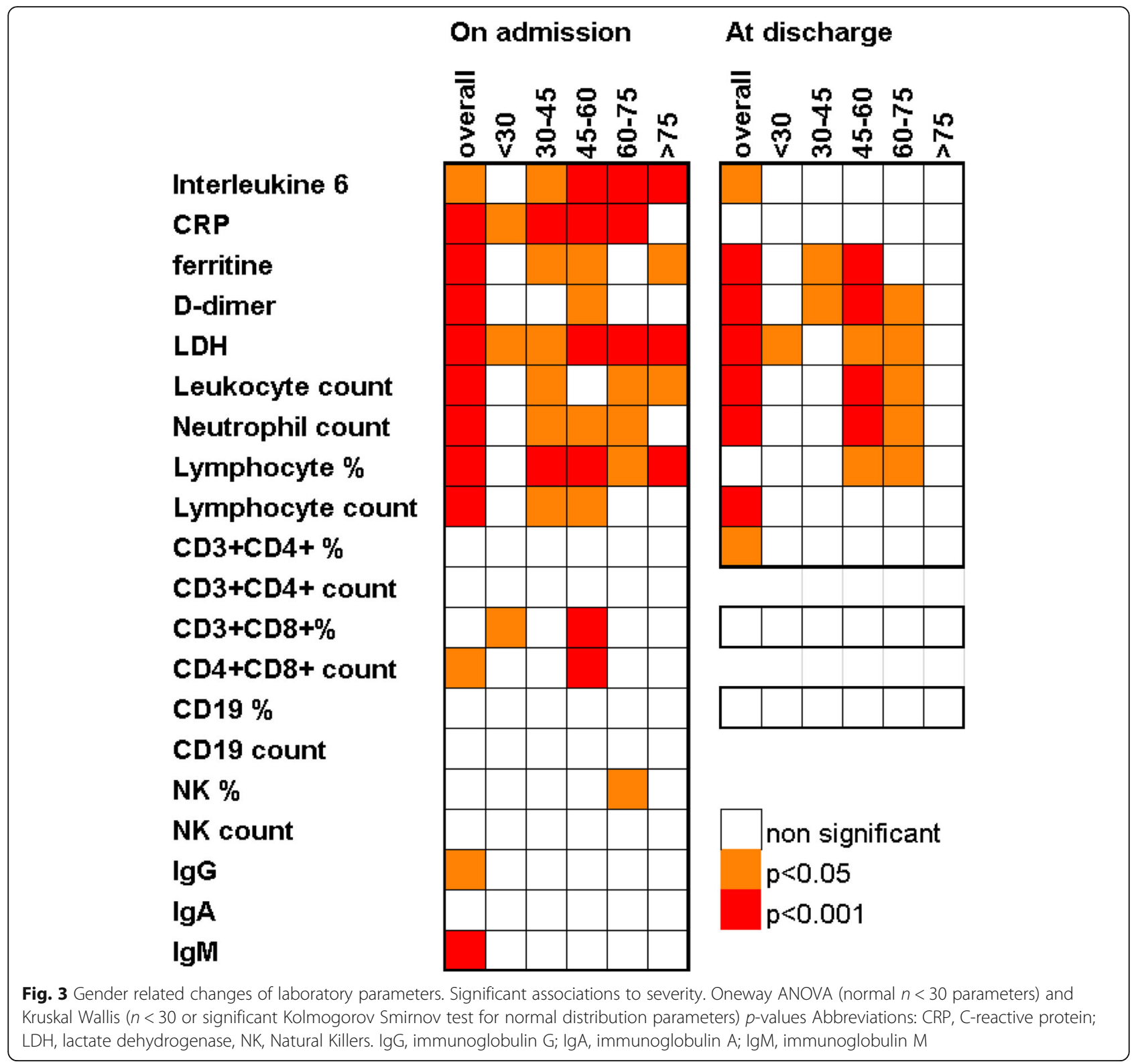

19 risk comorbidities, such as hypertension, diabetes, or dyslipidaemia. Angiotensin-converting enzyme inhibitors used by hypertensive patients would have a protective effect against COVID-19 severest forms, opposite to angiotensin II receptor blockers. Our patients are older and develop therefore a severe COVID-19 more often than the previously reported cohorts. Immunosenescence might be a suitable explanation for the immune overwhelming observed in the severest cases. Regarding not only our series but other ones around the world, the effectors of the immune system are hampered as severity increases. Adaptive immunity has been suggested to be disabled by SARSCoV-2. That feature has been referred to as immunity exhausted. This exhaustion may be coupled with a huge ineffective and almost deleterious innate response.
Further studies on the immune system status in SARSCoV-2 infected patients should be carried out to support the immunosenescence hypothesis as well as deeper analyses on RASB intake. Our data highlight that the elderly are at a special risk of COVID-19 and should therefore be monitored closely by public health services.

\section{Methods}

Aim, design, and setting of the study

This study aimed to reveal risk factors regarding severity by outlining, within the shortest possible time, a reliable snapshot of the demographic and clinical characteristics of COVID-19 patients admitted to Spanish hospitals along the first month of the pandemic. 


\section{Participants}

Our multicentre cohort consisted of the first consecutive set of SARS-CoV-2 infected inpatients, confirmed by a positive PCR test, during the second half of March 2020. Cases were tracked for a three-week follow-up period from admission to discharge. A minimum sample size of 20 patients was considered for every hospital. A total of 642 medical records of individuals over 18 years old, from 19 Spanish hospitals were initially reviewed. After data quality assessment, 584 patients were included in the analyses. Participants were stratified into three severity groups before analysis according to the following clinical criteria:

- Mild: individuals whose clinical symptoms were mild with no abnormal radiological findings

- Moderate: cases with confirmed, non-severe pneumonia

- Severe: those so considered by the physician in charge or meeting at least one of the following criteria: acute respiratory distress, shock, admission to the intensive care unit (ICU). Any "exitus" was as well classified as a severe case.

\section{Data collection}

All data were extracted from electronic medical records. The collection form included demographic, epidemiological and clinical data: age, sex, diabetes mellitus (DM), dyslipidaemia, hypertension (HTA), reninangiotensin system blocker intake (RASB), COVID-19 severity, time from symptom onset to diagnosis, laboratory data on admission and discharge, treatment, and outcome. At the end of data collection, some patients were still in the hospital. In these cases, laboratory data at discharge could not be provided.

\section{Laboratory data}

Requested laboratory markers were extracted from medical records on admission and at discharge. Routine blood examinations included leukocyte, neutrophil, and lymphocyte count (cells*10^3/ $\mu \mathrm{L}$ ) and lymphocyte percentage. Serum biochemical tests recorded were ferritin $(\mu \mathrm{g} / \mathrm{L})$, lactate dehydrogenase $(\mathrm{LDH}, \mathrm{U} / \mathrm{L}), \mathrm{C}$ - reactive protein $(\mathrm{CRP}, \mathrm{mg} / \mathrm{L})$, and $\mathrm{D}$-dimer $(\mu \mathrm{g} / \mathrm{L})$. Immunological tests recorded were interleukin-6 (IL-6, pg/mL),

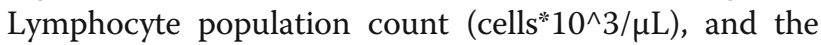
percentage by flow cytometry, immunoglobulins IgG, IgA, and IgM (mg/dL).

\section{Statistical analysis}

Demographic and clinical characteristics of patients were expressed as their mean and standard deviation (SD); when not adjusting to a normal distribution, the median was used to represent non-parametrical data for continuous variables and frequency distributions are reported for categorical variables. Age was analysed both, as a continuous and categorical variable, recoded then into 5 groups: $<30,30-45,45-$ $60,60-75$, and $>75$.

Continuous variables: 1. Normality testing: Kolmogorov-Smirnov test was performed on each continuous variable with more than 30 valid cases to contrast their normal distribution. Any variable with less than 30 valid cases was considered non-parametric for further hypothesis tests. 2. The difference of means (normal variables): To analyse the overall differences between the three groups: mild, moderate, and severe, ANOVA was tested on variables with normal distribution and $n>30$ (age, percentage and CD4 lymphocyte count, percentage of CD8 lymphocytes, percentage of CD19 lymphocytes and percentage of NK). 3. The difference of medians: To analyse severity relationships of non-parametric or $n<30$ variables, a Kruskal-Wallis test was used. 4. Changes along COVID-19: To compare values of recurrent parameters measured in the same case on admission and at discharge, the Wilcoxon test for paired data was performed. Categorical variables: To contrast the "Ho" of independence within categorical variables, Pearson's Chi-square and Fisher's exact test were used.

\section{Abbreviations}

ACE2: Angiotensin-converting enzyme 2; ACEl: Angiotensin-converting enzyme inhibitors; ARB: Angiotensin II receptor blockers; RASB: Reninangiotensin system blockers; LDH: Lactate dehydrogenase; CRP: C- reactive protein; IL-6: Interleukin-6; IgG: Immunoglobulin G; IgA: Immunoglobulin A; IgM: Immunoglobulin M; PCR: Polymerase chain reaction; SD: Standard deviation; IQR: Interquartile range; NK: Natural Killers

\section{Acknowledgements}

The authors thank all caregivers who indirectly contributed to this multicentre study. They also thank Sharleen Opia for her review of the English translation. They also thank the Spanish Society for Immunology (Sociedad Española de Inmunología, SEl) for its support and endorsement.

\section{Authors' contributions}

AJ and MCM conceived the idea for this study, designed the protocol, analysed the data and drafted the manuscript. The remaining authors collected the data, and assessed for data quality. All authors provided critical revisions and approved the final version of the manuscript.

\section{Funding}

This work has been carried out without funding.

\section{Availability of data and materials}

All collected data, including fully anonymized participant data, are available to others. Available information includes fully anonymized participant data and data dictionary. Related documents are available from the date of publications henceforth: study protocol, statistical analysis, and approval of the ethical board. These documents are available from the date of publications henceforth at email address cmartinalo@saludcastillayleon.es or aurora.jurado.sspa@juntadeandalucia.es

Data will be shared after approval of proposals by the Valladolid Este Ethical Committee.

Ethics approval and consent to participate

This study was conducted according to national regulations, institutional policies, and in the tenets of the Helsinki Declaration. This study was 
approved, with the Valladolid Health Area Drug Research Ethics Committee acting as the main committee, in a meeting held on March 31, 2020, and with the reference number "PI 20-172-NO-HCU". Moreover, it was approved by each of the local institutional Ethics Committee of the 19 hospitals involved.

\section{Competing interests}

The authors stated no conflicts of interest.

\section{Author details}

'Department of Immunology and Allergology, Hospital Universitario Reina Sofía-Instituto de Investigación Biomédica de Córdoba (IMIBIC), Córdoba, Spain. ${ }^{2}$ Centro de Hemoterapia y Hemodonación de Castilla y León, Paseo de Filipinos s/n, 47007 Valladolid, Spain. ${ }^{3}$ Department of Microbiology and Immunology, Hospital Clínico Universitario, Valladolid, Spain. ${ }^{4}$ Laboratory Unit. Complejo Hospitalario, Jaén, Spain. 5 Laboratoy of Immunology and Genetics. Hospital San Pedro de Alcántara, Cáceres, Spain. 'Laboratory Unit. Hospital Juan Ramón Jiménez, Huelva, Spain. ${ }^{7}$ Department of Immunology, Hospital Germans Trias i Pujols, Barcelona, Spain. ${ }^{8}$ Department of Immunology, Hospital Universitario Vall d'Hebron, Barcelona, Spain. ${ }^{9}$ Department of Immunology, Hospital General Universitario e Instituto de Investigación Sanitaria "Gregorio Marañón", Madrid, Spain. ${ }^{10}$ Unit of Immunology, Hospital Universitario Insular-Materno Infantil, Las Palmas de Gran Canaria, Spain. ${ }^{11}$ Department of Immunology, Complejo Hospitalario, La Coruña, Spain. ${ }^{12}$ Laboratory Unit. Hospital General, Alicante, Spain.

${ }^{13}$ Laboratory Unit. Hospital General Universitario, Albacete, Spain.

${ }^{14}$ Department of Immunology, Hospital Universitario Marqués de Valdecilla, Santander, Spain. ${ }^{15}$ Department of Immunology, Hospital Infanta Cristina, Badajoz, Spain. ${ }^{16}$ Laboratory Unit. Complejo Hospitalario Nuestra Señora de la Candelaria, Santa Cruz de Tenerife, Spain. ${ }^{17}$ Department of Immunology, Fundación Jiménez Díaz, Madrid, Spain. ${ }^{18}$ Department of Immunology, Hospital de Donostia, San Sebastián, Spain. ${ }^{19}$ Department of Immunology, Hospital Clínico Universitario, Salamanca, Spain. ${ }^{20}$ Department of Immunology, Hospital Universitario Son Espases, Palma de Mallorca, Spain.

Received: 25 May 2020 Accepted: 26 July 2020

Published online: 14 August 2020

\section{References}

1. Du Toit A. Outbreak of a novel coronavirus. Nat Rev Microbiol. 2020;18(3): 123.

2. COVID-19 Dashboard by the Center for Systems Science and Engineering (CSSE) at Johns Hopkins University (JHU). Available at: https://coronavirus. jhu.edu/map.html. Accessed 11 July 2020.

3. Kenji Mizumoto K, Gerardo CG. Estimating Risk for Death From 2019 Nove Coronavirus Disease, China, January-February 2020. Emerg Infect Dis. 2020; 26(6). https://doi.org/10.3201/eid2606.200233.

4. Oksanen A, Kaakinen M, Latikka R, Savolainen I, Savela N, Koivula A. Regulation and trust: 3-month follow-up study on COVID-19 mortality in 25 european countries. JMIR Public Health Surveill. 2020;6(2):e19218.

5. Cui J, Li F, Shi ZL. Origin and evolution of pathogenic coronaviruses. Nat Rev Microbiol. 2019;17(3):181-92.

6. Sanche S, Lin YT, Xu C, Romero-Severson E, Hengartner N, Ke R. High contagiousness and rapid spread of severe acute respiratory syndrome coronavirus 2. Emerg Infect Dis. 2020;26(7). https://doi.org/10.3201/eid2607. 200282.

7. Zou X, Chen K, Zou J, Han P, Hao J, Han Z. Single-cell RNA-seq data analysis on the receptor ACE2 expression reveals the potential risk of different human organs vulnerable to 2019-nCoV infection. Front Med. 2020:1-8. https://doi.org/10.1007/s11684-020-0754-0.

8. Lu R, Zhao X, Li J, Niu P, Yang B, Wu H. Genomic characterisation and epidemiology of 2019 novel coronavirus: implications for virus origins and receptor binding. Lancet. 2020;395(10224):565-74.

9. Wysocki J, Ye M, Rodriguez E, González-Pacheco FR, Barrios C, Evora K, et al. Targeting and degradation of angiotensin II with recombinant angiotensinconverting enzyme 2: prevention of angiotensin II-dependent hypertension. Hypertension. 2010;55(1):90-8.

10. Fang L, Karakiulakis $G$, Roth M. Are patients with hypertension and diabetes mellitus at increased risk for COVID-19 infection? Lancet Respir Med. 2020; 8(4):e21.
11. Batlle D, Wysocki J, Satchell K. Soluble angiotensin-converting enzyme 2: a potential approach for coronavirus infection therapy? Clin Sci [Lond]. 2020 134(5):543-5.

12. Cai $G$, Bossé $Y$, Xiao $F$, Kheradmand $F$, Amos $C l$. Tobacco smoking increases the lung gene expression of ACE2, the receptor of SARS-CoV-2. Am J Respir Crit Care Med. 2020. https://doi.org/10.1164/rccm.202003-0693LE.

13. Shi Y, Wang Y, Shao C, Huang J, Gan J, Huang X, et al. COVID-19 infection: the perspectives on immune responses. Cell Death Differ. 2020;27(5):1451-4.

14. Diao B, Wang C, Tan Y, Chen X, Liu Y, Ning L, et al. Reduction and Functional Exhaustion of T Cells in Patients with Coronavirus Disease 2019 (COVID-19). Front Immunol. 2020. https://doi.org/10.3389/fimmu-2020.00827.

15. Channappanavar R, Perlman S. Pathogenic human coronavirus infections: causes and consequences of cytokine storm and immunopathology. Semin Immunopathol. 2017;39(5):529-39.

16. Zheng F, Tang W, Li H, Huang YX, Xie YL, Zhou ZG. Clinical characteristics of 161 cases of corona virus disease 2019 [COVID-19] in Changsha. Eur Rev Med Pharmacol Sci. 2020;24(6):3404-10.

17. Liang WH, Guan WJ, Li CC, Li YM, Liang HR, Zhao Y, et al. Clinical characteristics and outcomes of hospitalized patients with COVID-19 treated in Hubei [epicenter] and outside Hubei [non-epicenter]: a Nationwide analysis of China. Eur Respir J. 2020;2000562. https://doi.org/10.1183/ 13993003.00562-2020.

18. Tian S, Hu N, Lou J, Chen K, Kang X, Xiang Z, et al. Characteristics of COVID19 infection in Beijing. J Inf Secur. 2020;80(4):401-6.

19. Feng $Y$, Ling $Y$, Bai T, Xie $Y$, Huang J, Li J. COVID-19 with different severity: a multi-Centre study of clinical features. Am J Respir Crit Care Med. 2020. https://doi.org/10.1164/rccm.202002-04450C.

20. Zhou F, Yu T, Du R, Fan G, Liu Y, Liu Z, et al. Clinical course and risk factors for mortality of adult inpatients with COVID-19 in Wuhan, China: a retrospective cohort study. Lancet. 2020;395(10229):1054-62.

21. Qin C, Zhou L, Hu Z, Zhang S, Yang S, Tao Y. Dysregulation of immune response in patients with COVID-19 in Wuhan, China. Clin Infect Dis. 2020. https://doi.org/10.1093/cid/ciaa248.

22. Li LQ, Huang T, Wang YQ, Wang ZP, Liang Y, Huang TB. COVID-19 patients' clinical characteristics, discharge rate, and fatality rate of meta-analysis. J Med Virol. 2020. https://doi.org/10.1002/jmv.25757.

23. Wu C, Chen X, Cai Y, Xia J, Zhou X, Xu S, et al. Risk factors associated with acute respiratory distress syndrome and death in patients with coronavirus disease 2019 pneumonia in Wuhan, China. JAMA Intern Med. 2020;13. https://doi.org/10.1001/jamainternmed.2020.0994.

24. Cao J, Tu WJ, Cheng W, Yu L, Liu YK, Hu X. Clinical features and short-term outcomes of 102 patients with corona virus disease 2019 in Wuhan, China. Clin Infect Dis. 2020. https://doi.org/10.1093/cid/ciaa243.

25. Grasselli G, Zangrillo A, Zanella A, Antonelli M, Cabrini L, Castelli A. Baseline characteristics and outcomes of 1591 patients infected with SARS-CoV-2 admitted to ICUs of the Lombardy region, Italy. JAMA. 2020;6. https://doi. org/10.1001/jama.2020.5394.

26. JCai J, Xu J, Lin D, Yang Z, Xu L, Qu Z, et al. A Case Series of children with 2019 novel coronavirus infection: clinical and epidemiological features. Clin Infect Dis. 2020;ciaa198. https://doi.org/10.1093/cid/ciaa198.

27. Koff WC, Williams MA. Covid-19 and Immunity in Aging Populations. A new research agenda. N Engl J Med. 2020. https://doi.org/10.1056/ NEJMp2006761.

28. Pera A, Campos C, López N, Hassouneh F, Alonso C, Tarazona R, et al. Immunosenescence: implications for response to infection and vaccination in older people. Maturitas. 2015;82(1):50-5.

29. Crooke SN, Ovsyannikova IG, Poland GA, Kennedy RB. Immunosenescence and human vaccine immune responses. Immun Ageing. 2019;16:25. https:// doi.org/10.1186/s12979-019-0164-9.

30. Instituto Nacional de Estadística. Ministerio de Economía y Hacienda. Gobierno de España. Available at: https://www.ine.es/jaxi/Tabla. htm?path=/t20/e245/p04/provi//0/\&file=0ccaa003.px\&L=0. Accessed 3 May 2020.

31. Chen G, Wu D, Guo W, Cao Y, Huang D, Wang H, et al. Clinical and immunological features of severe and moderate coronavirus disease 2019. J Clin Inves. 2019. https://doi.org/10.1172/JCl137244.

32. Soriguer F, Valdes S, Rojo G. The Di@bet.es study: and now what? Av Diabeto. 2012;28(2):35-7.

33. Menéndez E, Delgado E, Fernández-Vega F, Prieto MA, Bordiú E. Prevalence, diagnosis, treatment, and control of hypertension in Spain. Results of the Di@bet.es study. Rev Esp Cardiol. 2016;69(6):572-8. 
34. Felsenstein S, Herbert JA, Paul S, McNamara P, Hedrich CM. COVID-19: Immunology and treatment options. Clin Immunol. 2020;215:108448. https://doi.org/10.1016/j.clim.2020.108448.

35. Wan S, Yi Q, Fan S, Lv J, Zhang X, Guo L, et al. Relationships among lymphocyte subsets, cytokines, and the pulmonary inflammation index in coronavirus [COVID-19] infected patients. Br J Haematol. 2020;189(3):428-37.

36. Jensen IJ, Sjaastad FV, Griffith TS, Badovinac VP. Sepsis-Induced T Cell Immunoparalysis: the ins and outs of impaired T cell immunity. J Immunol. 2018;200(5):1543-53. https://doi.org/10.4049/jimmunol.1701618.

37. Fung $S Y$, Yuen $K S$, Ye ZW, Chan CP, Jin DY. A tug-of-war between severe acute respiratory syndrome coronavirus 2 and host antiviral defence: lessons from other pathogenic viruses. Emerg Microbes Infect. 2020;9(1):558-70.

38. Qu R, Ling Y, Zhang YH, Wei LI, Chen X, Li XM, et al. Platelet-to-lymphocyte ratio is associated with prognosis in patients with Corona virus Disease-19. J Med Virol. 2020. https://doi.org/10.1002/jmv.25767.

39. Tay MZ, Poh CM, Renia L, MacAry PA, Ng LFP. The trinity of COVID-19: immunity, inflammation and intervention. Nat Rev Immunol. 2020;20:36374

40. Azkur AK, Akdis M, Azkur D, Sokolowska M, van de Veen W, Brüggen MC, O'Mahony L, Gao Y, Nadeau K, Akdis CA. Immune response to SARS-CoV-2 and mechanisms of immunopathological changes in COVID-19. Allergy. 2020;10(111). https://doi.org/10.1111/all.14364.

41. Rico-Mesa JS, White A, Anderson AS. Outcomes in patients with COVID-19 infection taking ACEI/ARB. Curr Cardiol Rep. 2020;22(5):31.

42. Sommerstein R, Kochen MM, Messerli FH, Gräni C. Coronavirus disease 2019 [COVID-19]: do angiotensin-converting enzyme inhibitors/angiotensin receptor blockers have a biphasic effect? J Am Heart Assoc. 2020;9(7): e016509.

43. Hanff TC, Harhay MO, Brown TS, Cohen JB, Mohareb AM. Is There an Association Between COVID-19 Mortality and the Renin-Angiotensin System - a Call for Epidemiologic Investigations. Clin Infect Dis. 2020; ciaa329. https://doi.org/10.1093/cid/ciaa329.

44. Sommerstein R. Re: preventing a covid-19 pandemic: ACE inhibitors as a potential risk factor for fatal Covid-19. BMJ. 2020;368:m81 www.bmj.com/ content/368/bmj.m810/rr-2.

45. Wang Q, Zhang Y, Wu L, Niu S, Song C, Zhang Z, et al. Structural and functional Basis of SARS-CoV-2 entry by using human ACE2. Cell. 2020;20. 30338-X:S0092-8674. https://doi.org/10.1016/j.cell.2020.03.045.

46. Ciaglia E, Vecchione C, Puca AA. COVID-19 infection and circulating ACE2 levels: protective role in women and children. Front Pediatr. 2020;8:206. https://doi.org/10.3389/fped.2020.00206.

47. Tedeschi S, Giannella M, Bartoletti M, Trapani F, Tadolini M, Borghi C, et al. Clinical impact of renin-angiotensin system inhibitors on in-hospital mortality of patients with hypertension hospitalized for COVID-19. Clin Infect Dis. 2020;ciaa492. https://doi.org/10.1093/cid/ciaa492.

48. Mancia G, Rea F, Ludergnani M, Apolone G, Corrao G. Renin-angiotensinaldosterone system blockers and the risk of Covid-19. N Engl J Med. 2020; 382:2431-40.

\section{Publisher's Note}

Springer Nature remains neutral with regard to jurisdictional claims in published maps and institutional affiliations.

Ready to submit your research? Choose BMC and benefit from:
- fast, convenient online submission
- thorough peer review by experienced researchers in your field
- rapid publication on acceptance
- support for research data, including large and complex data types
- gold Open Access which fosters wider collaboration and increased citations
- maximum visibility for your research: over 100M website views per year
At BMC, research is always in progress.
Learn more biomedcentral.com/submissions

